\title{
Basaloid Squamous Cell Carcinoma of the Head and Neck
}

\section{A Clinicopathological and Follow-Up Study of 40 Cases and Review of the Literature}

\author{
Cosme Ereño $\cdot$ Ayman Gaafar $\cdot$ Maddi Garmendia Carmen Etxezarraga \\ Francisco J. Bilbao $\cdot$ José I. López
}

Received: 16 February 2008 / Accepted: 18 February 2008/Published online: 21 March 2008

(c) Humana 2008

\begin{abstract}
Basaloid squamous cell carcinoma (BSCC) is a rare and aggressive variant of cancer that mainly arises in the upper aerodigestive tract. This study reviews the clinicopathological features and follow-up of a series of cases occurring in the head and neck. During a 32-year period (1974-2005), a total of 40 BSCCs have been diagnosed in the head and neck in our Institution. Males predominated in the series $(35 \mathrm{M} / 5 \mathrm{~F})$. The average age was 60.2 years (range, 40 $85)$. Tobacco and alcohol consumption was found in more than $80 \%$ of the cases. Topographic distribution was as follows: larynx and hypopharynx, 22 cases (55\%); oropharynx, 12 cases (30\%); and oral cavity 6 cases $(15 \%)$. The basaloid component predominated in 29 cases $(72.5 \%)$. Vasculolymphatic invasion was detected in 5 cases $(12.5 \%)$. Lymph node metastases were seen in 25 cases $(62.5 \%$, levels II and III in the neck dissection). Local recurrences appeared in 11 cases $(27.5 \%)$ and distant metastases in $6(15 \%)$. In 7 cases $(17.5 \%)$ a second primary tumour was detected. The 2002 TNM staging was as follows: Stage I, 5 cases (12.5\%); Stage II, 7 cases (17.5\%); Stage III, 8 cases (20\%), and Stage IV, 20 cases (50\%). On follow-up, 21 cases (52.5\%) are alive and 19 $(47.5 \%)$ died of disease. Three- and 5-year overall survival
\end{abstract}

This piece of knowledge has been partially presented as a poster (abstract \#1017) in the 96th Annual Meeting of the United States and Canadian Academy of Pathology, in San Diego, CA, March 24-30, 2007.

C. Ereño $(\bowtie) \cdot$ A. Gaafar · M. Garmendia · C. Etxezarraga · F. J. Bilbao

Department of Pathology, Hospital de Basurto, Basque Country

University, Avda. De Montevideo 18, Bilbao 48013, Spain

e-mail: cosme.erenozarate@osakidetza.net

J. I. López

Department of Pathology, Hospital de Cruces, Barakaldo,

Basque Country University (EHU/UPV), Bizkaia, Spain was $50 \%$ and $38.5 \%$, respectively. A significant shorter survival was detected in node positive patients $(P<0.05)$.

Keywords Basaloid-squamous cell carcinoma . Head and neck · Larynx · Hypopharynx · Oropharynx · Oral cavity · Differential diagnosis · Prognosis . Recurrence $\cdot$ Metastasis

\section{Introduction}

Basaloid squamous cell carcinoma (BSCC) was first described in 1986 by Wain et al. [1] in the tongue, larynx and hypopharynx as a distinctive histological variant of squamous cell carcinoma with aggressive behaviour. Upper aerodigestive tract is the most common site of origin of this tumour in the head and neck [2,3], especially epiglottis, hypopharynx (piriform sinus) and base of the tongue $[4,5]$. Other less common sites of origin in this region include floor of the mouth, oral mucosa, palate, tonsils, sinonasal tract, nasopharynx, and trachea [6-11]. Additionally, BSCC has been reported in oesophagus, lung, anus, cervix uteri, penis and urinary bladder [12-17].

The present paper presents the clinico-pathological study with long term follow-up of a large series of BSCCs arising in the head and neck region.

\section{Materials and Methods}

During a period of 32 years (1974-2005), a total of 40 BSCCs have been diagnosed in the head and neck in the Hospital de Basurto, Basque Country University, Bilbao, Spain. The cases were collected prospectively since 1987 and retrospectively before this date. All the cases met the histological criteria 
proposed by Wain et al. [1]. Follow-up was closed by June 2006.

All the cases were reviewed at least by two pathologists who applied the Wain's criteria for the diagnosis of this tumour [(Basaloid component: solid growth, cellularity, nuclei, mitoses, cystic spaces, necrosis and hyalinosis), (Squamous component: keratinization, intercellular bridging, horny pearls, mosaic pattern)] [1]. The cases were considered predominantly basaloid when this component represented more than $75 \%$ of the tumour. Discrepancies between pathologists were reconciled on a multihead microscope. The pathologic staging was based on the 2002 TNM/AJCC classification [18].

Survival was estimated by the Kaplan-Meier (log-rank) method using the SPSS software for Windows (version 14.1, Chicago, USA).

\section{Results}

\section{Clinical Data}

Males predominated in the series, accounting for $87.5 \%$ of the cases $(35 \mathrm{M} / 5 \mathrm{~F})$. The average age was 60.2 years (range, 40-85). Tobacco and alcohol consumption was recorded in the clinical history in more than $80 \%$ of the patients. More than half of tumours arose in the larynx and hypopharynx (22 cases, $55 \%$ ), followed by oropharynx (12 cases, $30 \%$ ), and oral cavity (6 cases, 15\%). Main clinicopathological data of each group are reflected in Tables 1, 2, and 3.

Primary tumours and loco-regional recurrences were treated with surgery followed by radio- and chemotherapy.

\section{Pathological Data}

Grossly, most tumours showed an ulcerating-infiltrating growth pattern $(95.5 \%)$ and a solid and whitish cut surface with expansive borders (Fig. 1). Average diameter of tumours was $24.4 \mathrm{~mm}$ (range, 5-55). On light microscopy, the tumour was basically composed of irregular tumour nests with basaloid (Fig. 2) (small cells, hyperchromatic atypical nuclei, frequent mitoses, scarce cytoplasm, peripheral palisading) (Fig. 3) appearance centered by squamous, sometimes keratinizing (Fig. 4), cells in a highly collagenized stroma. A predominantly basaloid histology was seen in 30 cases $(73.1 \%)$. Wain's criteria

Table 1 Clinicopathological findings in 22 basaloid squamous cell carcinomas of the larynx and hypopharynx

\begin{tabular}{|c|c|c|c|c|c|c|c|c|c|c|c|}
\hline Case & $\mathrm{A} / \mathrm{S}$ & Origin & Basal C & VL inv & Lymph node & Level & Staging & Follow-up (months) & Loc Rec & Dist Met & SPT \\
\hline 1 & $49 / \mathrm{M}$ & Transglottic & +++ & Yes & $\mathrm{pN} 1$ & III & 3 & 10-DOD & - & - & - \\
\hline 2 & $62 / \mathrm{M}$ & Vallecula & +++ & No & $\mathrm{pN} 2 \mathrm{~B}$ & III & 4 & 35-DOD & - & - & - \\
\hline 3 & $42 / \mathrm{M}$ & Left piriform & +++ & Yes & $\mathrm{pN} 2 \mathrm{~B}$ & III & 4 & 18-DOD & - & - & - \\
\hline 4 & $63 / \mathrm{M}$ & Supraglottic & +++ & Yes & $\mathrm{pN} 1 \mathrm{~B}$ & III & 3 & 25-DOD & - & - & Bronchus \\
\hline 5 & $63 / \mathrm{M}$ & Supraglottic & + & Yes & $\mathrm{pN} 1 \mathrm{~B}$ & III & 3 & 15-DOD & - & - & - \\
\hline 6 & $50 / \mathrm{M}$ & Supraglottic & + & No & - & - & 2 & 48-AwD & - & - & - \\
\hline 7 & $61 / \mathrm{M}$ & Supraglottic & + & No & - & - & 3 & 39-AwD & - & - & - \\
\hline 8 & $54 / \mathrm{M}$ & Supraglottic & +++ & No & $\mathrm{pN} 2 \mathrm{~b} \mathrm{~B}$ & III/IV & 4 & 14-DOD & +++ & Bone & - \\
\hline 9 & $56 / \mathrm{M}$ & Supraglottic & +++ & No & - & - & 1 & 71-AwD & - & - & - \\
\hline 10 & $75 / \mathrm{M}$ & Supraglottic & +++ & No & - & - & 1 & 36-AwD & - & - & - \\
\hline 11 & $58 / \mathrm{M}$ & Supraglottic & +++ & No & $\mathrm{pN} 2 \mathrm{~b} \mathrm{~B}$ & III & 4 & 6-DOD & +++ & - & - \\
\hline 12 & $65 / \mathrm{M}$ & Vallecula & +++ & No & $\mathrm{pN} 2 \mathrm{c} \mathrm{B}$ & III/IV & 4 & 45-DOD & +++ & Lung & - \\
\hline 13 & $52 / \mathrm{M}$ & Supraglottic & +++ & No & $\mathrm{pN} 1$ & Delph (mi) & 4 & 74-AwD & - & - & - \\
\hline 14 & $73 / \mathrm{M}$ & Glottic & +++ & No & - & - & 4 & 20-AwD & - & - & - \\
\hline 15 & $41 / \mathrm{F}$ & Supraglottic & +++ & No & $\mathrm{pN} 1 \mathrm{~B}$ & III/IV (mi) & 4 & 26-DOD & Tracheostoma & Lung & \\
\hline 16 & $75 / \mathrm{M}$ & Supraglottic & + & No & - & - & 3 & 12-AwD & - & - & - \\
\hline 17 & $61 / \mathrm{M}$ & Left piriform & + & No & $\mathrm{pN} 2 \mathrm{~B} \mathrm{E}-\mathrm{E}$ & III/IV & 2 & 13-DOD & +++ & - & - \\
\hline 18 & $57 / \mathrm{M}$ & Left piriform & +++ & No & pN1 E-E B & III & 3 & 83-AwD & - & - & - \\
\hline 19 & $62 / \mathrm{M}$ & Left pirifomr & +++ & Yes & pN2b E-E B & III & 4 & 8-DOD & - & - & - \\
\hline 20 & $64 / \mathrm{M}$ & Left piriform & +++ & No & pN1 E-E B & III & 3 & 11-AwD & - & - & - \\
\hline 21 & $62 / \mathrm{M}$ & Left piriform & +++ & No & pN2b E-E B & II/IV & 4 & 3-DOD & - & - & Bronchus \\
\hline 22 & $66 / \mathrm{M}$ & Left piriform & +++ & No & $\mathrm{pN} 2 \mathrm{c}$ E-E B & $\mathrm{II} / \mathrm{IV}$ & 4 & 17-AWD & - & - & Sinonasal \\
\hline
\end{tabular}

A/S: age and sex, Basal C: basal component (+++ abundant, + scarce), VL inv: vascular-lymphatic invasion, Lymph node: nodal status, Level: level of metastatic seed in neck dissection, Loc Rec: local recurrences, Dist Met: distant metastases, SPT: second primary tumour, B: biphasic (basaloid and squamous) tumour, E-E: extracapsular extension, delph: delphian node, (mi): microscopic, DOD: died of disease, AwD: alive without disease, AWD: alive with disease 
Table 2 Clinicopathological findings in 12 basaloid squamous cell carcinomas of the oropharynx

\begin{tabular}{|c|c|c|c|c|c|c|c|c|c|c|c|}
\hline Case & $\mathrm{A} / \mathrm{S}$ & Origin & Basal C & VL inv & Lymph node & Level & Staging & Follow-up (months) & Loc Rec & Dist Met & SPT \\
\hline 1 & $54 / \mathrm{M}$ & Left tonsil & +++ & No & pN2b E-E B & $\mathrm{II} / \mathrm{III}$ & 4 & 23-AWD & - & - & - \\
\hline 2 & $58 / \mathrm{F}$ & Right tonsil & + & No & $\mathrm{pN} 2 \mathrm{~b} \mathrm{~B}$ & $\mathrm{II} / \mathrm{III}$ & 4 & 12-AWD & +++ & - & - \\
\hline 3 & $63 / \mathrm{M}$ & Left tonsil & +++ & No & - & - & 1 & 9-DOD & - & Lung & Uvula \\
\hline 4 & $40 / \mathrm{F}$ & Right tonsil & +++ & No & - & - & 2 & 32-AWD & +++ & - & - \\
\hline 5 & $55 / \mathrm{M}$ & Right tonsil & + & No & - & - & 4 & 3-AWD & - & - & - \\
\hline 6 & $70 / \mathrm{M}$ & Left tonsil & + & No & - & - & 2 & 3-DOD & - & - & Bronchus \\
\hline 7 & $58 / \mathrm{F}$ & Left tonsil & +++ & No & pN2b E-E B & $\mathrm{II} / \mathrm{III}$ & 4 & 5-DOD & - & - & - \\
\hline 8 & $47 / \mathrm{M}$ & Base of tongue & +++ & No & $\mathrm{pN} 2 \mathrm{c} B$ & III & 4 & 6-AWD & - & - & - \\
\hline 9 & $85 / \mathrm{M}$ & Base of tongue & + & No & $\mathrm{pN} 1$ & II & 3 & 7-AWD & - & Bone & - \\
\hline 10 & $70 / \mathrm{M}$ & Base of tongue & + & No & $\mathrm{pN} 1 \mathrm{~B}$ & II & 4 & 6-DOD & - & - & Colon \\
\hline 11 & $65 / \mathrm{M}$ & Base of tongue & +++ & No & $\mathrm{pN} 2 \mathrm{c} \mathrm{B}$ & III/IV & 4 & 41-AWD & - & - & - \\
\hline 12 & $54 / \mathrm{M}$ & Oropharynx & +++ & No & - & - & 2 & 41-AWD & +++ & - & - \\
\hline
\end{tabular}

A/S: age and sex, Basal C: basal component (+++ abundant, + scarce), VL inv: vascular-lymphatic invasion, Lymph node: nodal status, Level: level of metastatic seed in neck dissection, Loc Rec: Local recurrences, Dist Met: distant metastases, SPT: second primary tumour, B: biphasic (basaloid and squamous) tumour, E-E: extracapsular extension, DOD: died of disease, AWD: alive with disease

Table 3 Clinicopathological findings in six basaloid squamous cell carcinomas of the oral cavity

\begin{tabular}{|c|c|c|c|c|c|c|c|c|c|c|c|}
\hline Case & $\mathrm{A} / \mathrm{S}$ & Origin & Basal C & VL inv & Lymph node & Level & Staging & Follow-up (months) & Loc Rec & Dist Met & SPT \\
\hline 1 & $65 / \mathrm{M}$ & Palate & +++ & No & - & - & 1 & 13-AwD & - & - & - \\
\hline 2 & $72 / \mathrm{M}$ & Palate & +++ & No & $\mathrm{pN} 2 \mathrm{~B}$ & II & 4 & 5-AWD & - & - & - \\
\hline 3 & $70 / \mathrm{F}$ & Palate & +++ & No & - & - & 2 & 11-AWD & +++ & - & - \\
\hline 4 & $54 / \mathrm{M}$ & Tongue & +++ & No & $\mathrm{pN} 2 \mathrm{~b}$ E-E B & II & 4 & 18-DOD & +++ & - & - \\
\hline 5 & $54 / \mathrm{M}$ & Mouth floor & + & No & - & - & 2 & 45-DOD & +++ & - & - \\
\hline 6 & $70 / \mathrm{M}$ & Oral mucosa & +++ & No & - & - & 1 & 1-DOD & - & - & - \\
\hline
\end{tabular}

A/S: age and sex, Basal C: basal component (+++ abundant, + scarce), VL inv: vascular-lymphatic invasion, Lymph node: nodal status, Level: level of metastatic seed in neck dissection, Loc Rec: Local recurrences, Dist Met: distant metastases, SPT: second primary tumour, B: biphasic (basaloid and squamous) tumour, E-E: extracapsular extension, DOD: died of disease, AWD: alive with disease

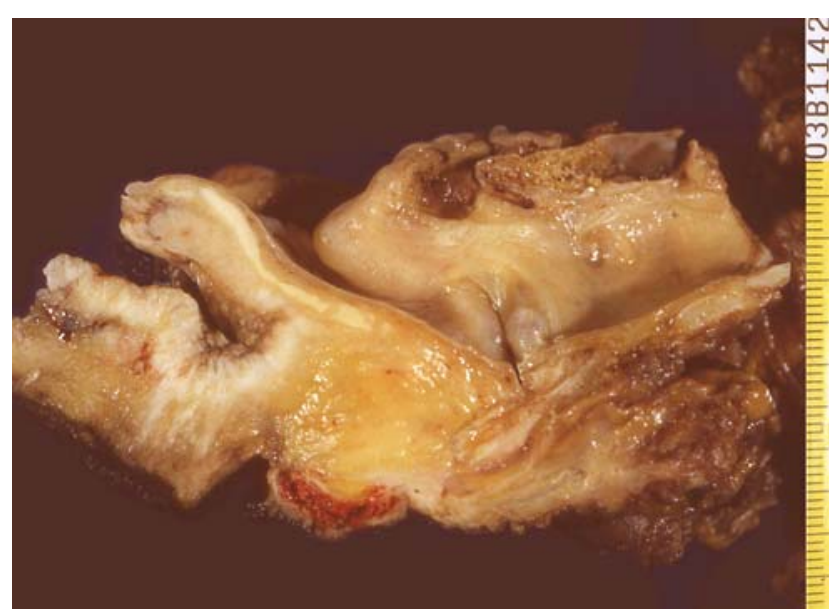

Fig. 1 Laryngectomy specimen showing a basaloid squamous cell carcinoma invading the base of tongue and laryngeal vallecula

of larynx and hypopharynx, oropharynx and oral cavity tumours appear reflected in Tables 4, 5, and 6, respectively.

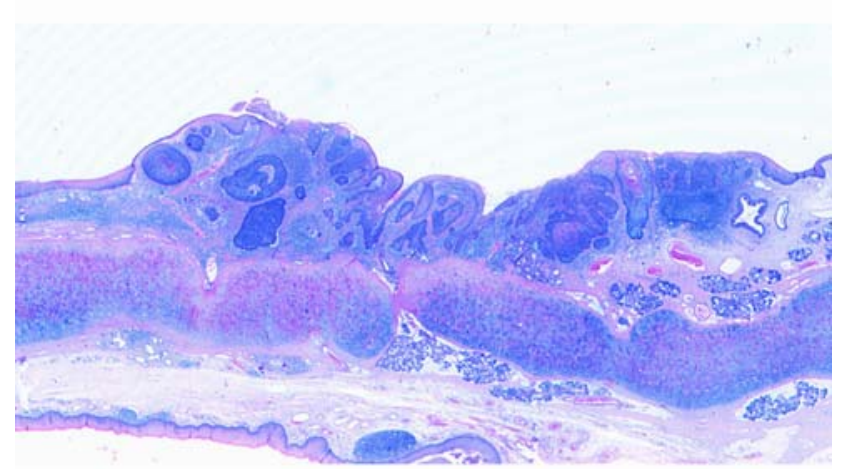

Fig. 2 Panoramic view of the superficial spreading area of a laryngeal basaloid squamous cell carcinoma displaying solid tumour nests of basaloid and squamous cells

\section{Laryngeal and Hypopharyngeal Tumours (22 cases) (Tables 1 and 4)}

Fifteen of 22 tumours (68.1\%) arising in this area showed a predominant basaloid pattern of growth, with typical cells 


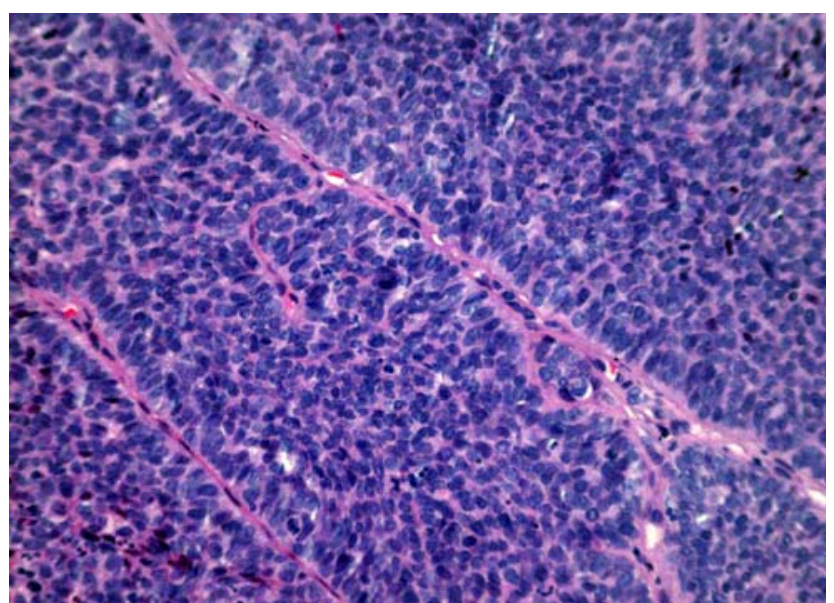

Fig. 3 Cytological detail showing a solid pattern of growth with prominent peripheral palisading

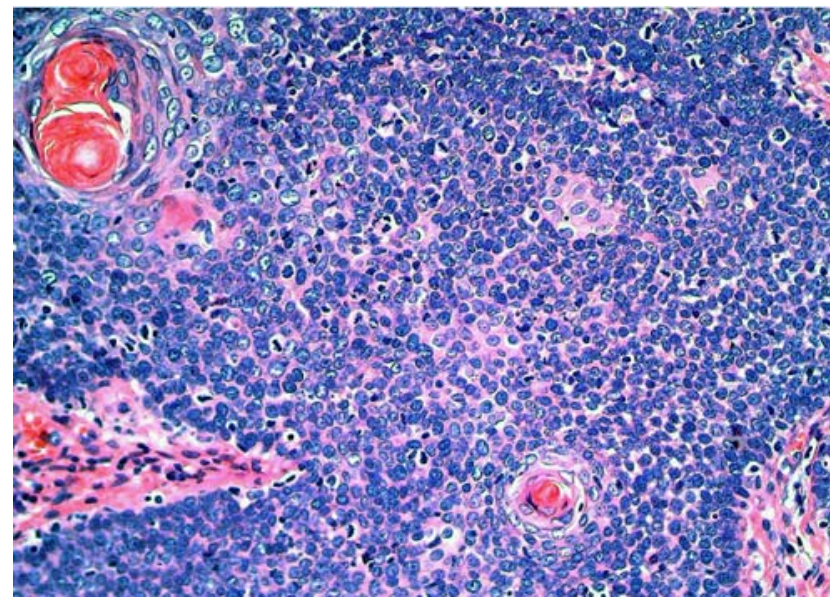

Fig. 4 Typical biphasic arrangement in a basaloid squamous cell carcinoma with squamous tumour nests centering basaloid areas

and solid arrangement (Figs. 2 and 3). Comedonecrosis (Fig. 5) was seen in 18 cases ( $81.8 \%$ ), being extensive in 12 of them. Stromal pericellular hyalinization (Fig. 6) was detected in 13 cases (59\%) and cystic spaces (Fig. 7) in 7 $(31.8 \%)$, being prominent in 3 . Local recurrences appeared in 5 patients $(22.7 \%)$. Sixteen cases $(72.7 \%)$ in this group showed lymph node metastases, which were more common in tumours arising in the piriform sinuses $(6 / 7,85.7 \%)$ than in the endolarynx $(9 / 15,60 \%)$. Tumour staging revealed 2 cases in Stage I, 2 in Stage II, 7 in Stage III and 11 in Stage IV (Fig. 8).

\section{Oropharyngeal Tumours (12 cases) (Tables 2 and 5)}

Nine of 12 tumours (75\%) of this group showed predominant basaloid pattern, with typical cytology and solid growth pattern. Comedonecrosis was observed in 9 cases
(75\%) being extensive in 6 . Stromal pericellular hyalinization was found in 6 cases $(50 \%)$, being prominent in 3 . One case $(8.3 \%)$ showed cystic spaces. Local recurrences were seen in 3 cases $(25 \%)$. Seven patients $(58.3 \%)$ presented lymph node metastases. Tumour staging showed 1 case in Stage I, 3 in Stage II, 1 in Stage III and 7 in Stage IV.

\section{Oral Cavity Tumours (6 cases) (Tables 3 and 6)}

Five of 6 tumours $(83.3 \%)$ located in this topography displayed a predominant basaloid growth pattern, with typical cells and solid arrangement. Comedonecrosis was observed in $100 \%$ of cases, being extensive in 2 . Pericellular hyalinization was found in 4 cases $(66.6 \%)$. Cystic spaces were not seen in any case. Local recurrences were found in 3 patients (50\%). Two cases (33.3\%) in this group had lymph node metastases. Tumour staging showed 2 cases in Stage I, 2 in Stage II, and 2 in Stage IV.

\section{Loco-regional Extension (Tables 1, 2, and 3)}

There was no statistical correlation between tumour histology (predominantly basaloid or not) and the presence of lymph node metastases or local recurrences. In the same sense, lymph node metastases were not statistically associated to tumour topography.

Perineural invasion was not seen in any case. Vascularlymphatic invasion was detected in 5 cases (12.5\%). All of them presented lymph node metastases and the patients died of the disease 8 to 25 months after the diagnosis. Global local recurrence of the tumour was $27.5 \%$ (11/40). Neck dissection specimens revealed lymph node metastases in 25 cases $(62.5 \%)$ in levels II and III, being biphasic, that is, basaloid and squamous, in 21 of them (84\%). Lymph node metastases showed extracapsular extension in 8 tumours (32\%), arising 5 in the hypopharynx, 2 in the oropharynx, and 1 in the oral cavity. Four cases $(16 \%)$ showed adventicial invasion in the neighbour jugular vein.

\section{Distant Metastases}

Distant metastases were detected in 6 cases (15\%) being 3 in the lung, 2 in bone, and 1 in the liver.

\section{Second Primary Tumours}

Metachronic second primary tumours were detected in 6 of 40 cases $(15 \%), 2$ of them being located in the upper aerodigestive tract, 3 in the bronchus, and 1 in the colon. 
Table 4 Wain's criteria in tumours of the larynx and hypopharynx

\begin{tabular}{|c|c|c|c|c|c|c|c|c|c|c|c|}
\hline \multirow[t]{2}{*}{ Case } & \multicolumn{7}{|c|}{ Basaloid component } & \multicolumn{4}{|c|}{ Squamous component } \\
\hline & $\%$ & $\begin{array}{l}\text { Solid } \\
\text { growth }\end{array}$ & Cellularity & Nuclei & $\begin{array}{l}\text { Cystic } \\
\text { spaces }\end{array}$ & Necrosis & Hyalinization & Keratinization & $\begin{array}{l}\text { Intercel } \\
\text { bridging }\end{array}$ & $\begin{array}{l}\text { Horny } \\
\text { pearls }\end{array}$ & $\begin{array}{l}\text { Mosaic } \\
\text { pattern }\end{array}$ \\
\hline 1 & 88 & +++ & +++ & +++ & + & +++ & +++ & + & - & + & - \\
\hline 2 & 81 & ++ & ++ & ++ & - & + & ++ & + & - & + & - \\
\hline 3 & 80 & +++ & +++ & +++ & +++ & +++ & + & + & + & + & + \\
\hline 4 & 50 & ++ & +++ & +++ & - & - & - & ++ & ++ & ++ & ++ \\
\hline 5 & 72 & ++ & +++ & +++ & +++ & + & + & ++ & ++ & ++ & ++ \\
\hline 6 & 41 & +++ & ++ & ++ & - & - & - & ++ & +++ & ++ & +++ \\
\hline 7 & 78 & +++ & +++ & +++ & +++ & +++ & +++ & + & + & + & + \\
\hline 8 & 76 & +++ & +++ & +++ & - & + & - & + & + & + & - \\
\hline 9 & 88 & +++ & +++ & +++ & + & +++ & ++ & + & - & + & - \\
\hline 10 & 77 & +++ & +++ & +++ & + & - & - & + & + & - & - \\
\hline 11 & 84 & +++ & +++ & ++ & - & + & ++ & + & + & - & - \\
\hline 12 & 71 & +++ & +++ & ++ & - & + & + & ++ & + & + & - \\
\hline 13 & 82 & +++ & +++ & +++ & - & +++ & ++ & + & + & + & - \\
\hline 14 & 87 & +++ & +++ & +++ & - & +++ & ++ & + & - & + & - \\
\hline 15 & 87 & +++ & +++ & +++ & - & +++ & ++ & + & + & - & - \\
\hline 16 & 66 & ++ & ++ & ++ & - & - & - & + & + & + & - \\
\hline 17 & 36 & + & + & + & - & + & - & +++ & ++ & ++ & - \\
\hline 18 & 87 & +++ & +++ & +++ & - & +++ & ++ & + & + & - & - \\
\hline 19 & 87 & +++ & +++ & +++ & + & ++ & ++ & + & - & + & - \\
\hline 20 & 91 & +++ & +++ & +++ & - & ++ & - & + & - & - & - \\
\hline 21 & 84 & +++ & +++ & +++ & - & ++ & - & + & + & - & - \\
\hline 22 & 73 & +++ & +++ & +++ & - & ++ & - & ++ & ++ & - & - \\
\hline
\end{tabular}

$\%$ : percentage of basaloid component

+++ abundant,++ moderate, + scarce,- absent

Table 5 Wain's criteria in tumours of the oropharynx

\begin{tabular}{|c|c|c|c|c|c|c|c|c|c|c|c|}
\hline \multirow[t]{2}{*}{ Case } & \multicolumn{7}{|c|}{ Basaloid component } & \multicolumn{4}{|c|}{ Squamous component } \\
\hline & $\%$ & $\begin{array}{l}\text { Solid } \\
\text { growth }\end{array}$ & Cellularity & Nuclei & $\begin{array}{l}\text { Cystic } \\
\text { spaces }\end{array}$ & Necrosis & Hyalinization & Keratinization & $\begin{array}{l}\text { Intercel } \\
\text { bridging }\end{array}$ & $\begin{array}{l}\text { Horny } \\
\text { pearls }\end{array}$ & $\begin{array}{l}\text { Mosaic } \\
\text { pattern }\end{array}$ \\
\hline 1 & 93 & +++ & +++ & +++ & - & ++ & +++ & + & - & - & - \\
\hline 2 & 53 & ++ & ++ & + & - & ++ & - & +++ & ++ & + & - \\
\hline 3 & 76 & +++ & +++ & +++ & - & + & - & + & + & + & - \\
\hline 4 & 88 & +++ & +++ & +++ & - & +++ & +++ & + & - & + & - \\
\hline 5 & 81 & +++ & +++ & +++ & - & - & - & + & - & + & - \\
\hline 6 & 72 & ++ & ++ & ++ & - & ++ & - & + & + & + & - \\
\hline 7 & 82 & +++ & +++ & +++ & - & ++ & +++ & + & + & + & - \\
\hline 8 & 77 & +++ & +++ & +++ & + & +++ & + & ++ & + & + & - \\
\hline 9 & 75 & +++ & +++ & +++ & - & - & - & + & + & + & - \\
\hline 10 & 58 & ++ & +++ & ++ & - & - & - & ++ & ++ & + & - \\
\hline 11 & 76 & +++ & +++ & ++ & - & + & + & + & + & + & - \\
\hline 12 & 85 & +++ & +++ & +++ & - & + & ++ & + & + & - & - \\
\hline
\end{tabular}

$\%$ : percentage of basaloid component

+++ abundant, ++ moderate, + scarce, - absent 
Table 6 Wain's criteria in tumours of the oral cavity

\begin{tabular}{|c|c|c|c|c|c|c|c|c|c|c|c|}
\hline \multirow[t]{2}{*}{ Case } & \multicolumn{7}{|c|}{ Basaloid component } & \multicolumn{4}{|c|}{ Squamous component } \\
\hline & $\%$ & $\begin{array}{l}\text { Solid } \\
\text { growth }\end{array}$ & Cellularity & Nuclei & $\begin{array}{l}\text { Cystic } \\
\text { spaces }\end{array}$ & Necrosis & Hyalinization & Keratinization & $\begin{array}{l}\text { Intercel } \\
\text { bridging }\end{array}$ & $\begin{array}{l}\text { Horny } \\
\text { pearls }\end{array}$ & $\begin{array}{l}\text { Mosaic } \\
\text { pattern }\end{array}$ \\
\hline 1 & 83 & +++ & +++ & +++ & - & + & - & + & + & - & - \\
\hline 2 & 83 & +++ & ++ & +++ & - & + & + & + & + & - & - \\
\hline 3 & 83 & +++ & +++ & +++ & - & + & - & + & + & - & - \\
\hline 4 & 87 & +++ & +++ & +++ & - & +++ & ++ & + & + & - & - \\
\hline 5 & 45 & + & ++ & ++ & - & ++ & - & +++ & +++ & ++ & - \\
\hline 6 & 78 & +++ & +++ & +++ & - & + & + & + & + & + & - \\
\hline
\end{tabular}

$\%$ : percentage of basaloid component

+++ abundant, ++ moderate, + scarce, - absent

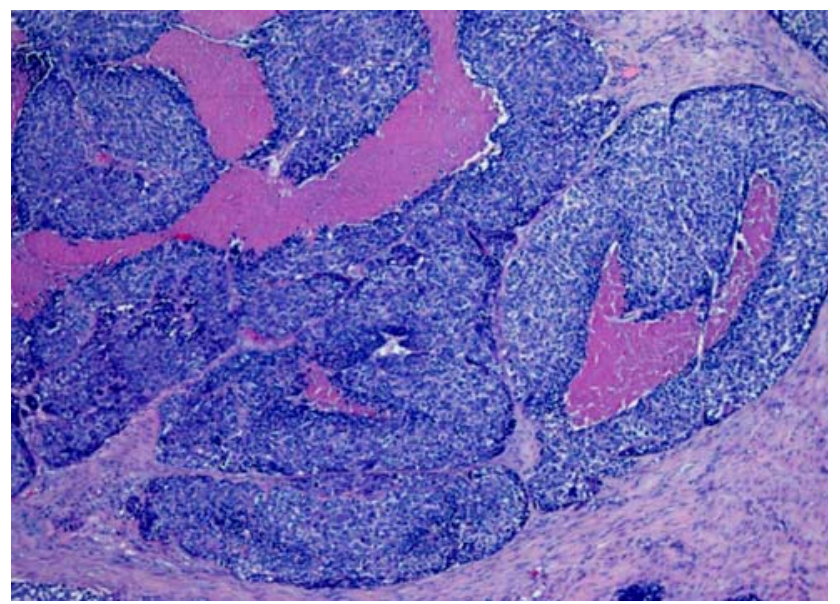

Fig. 5 Comedonecrosis is a prominent feature in $27.5 \%$ of basaloid squamous cell carcinomas

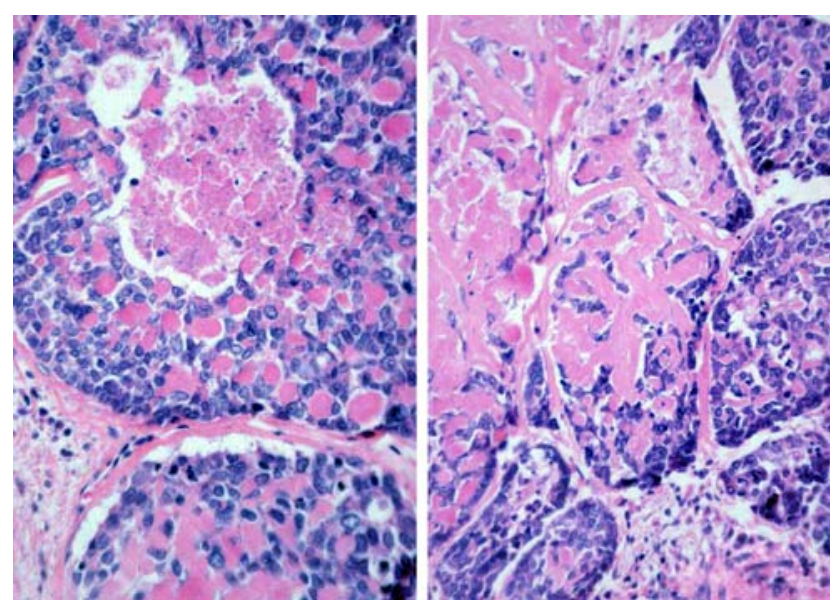

Fig. 6 Cytological detail showing a solid pattern of growth with prominent pericellular hyalinization

\section{Follow-up}

Average follow-up for tumours arising in the larynx and hypopharynx was 28.5 months (range, 3-83), 15.6 months

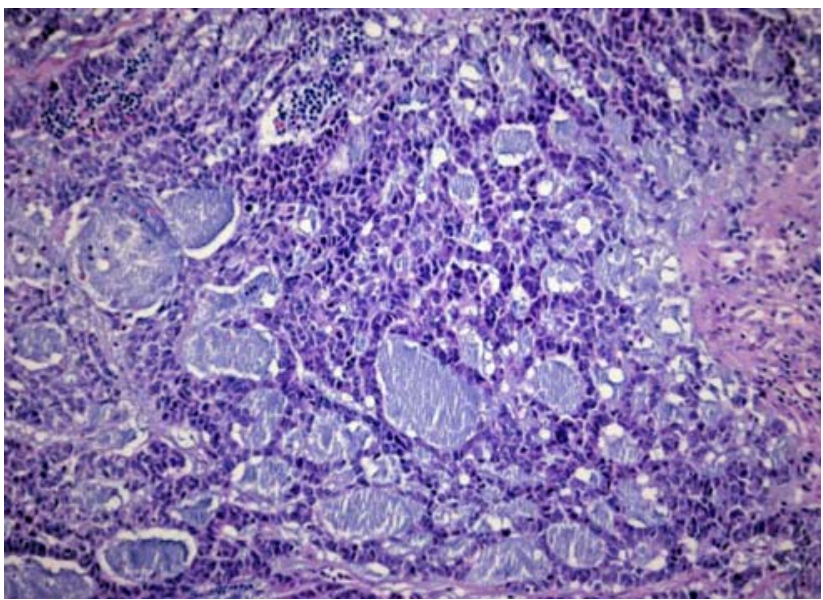

Fig. 7 Cytological detail showing a solid pattern of growth with small cystic spaces
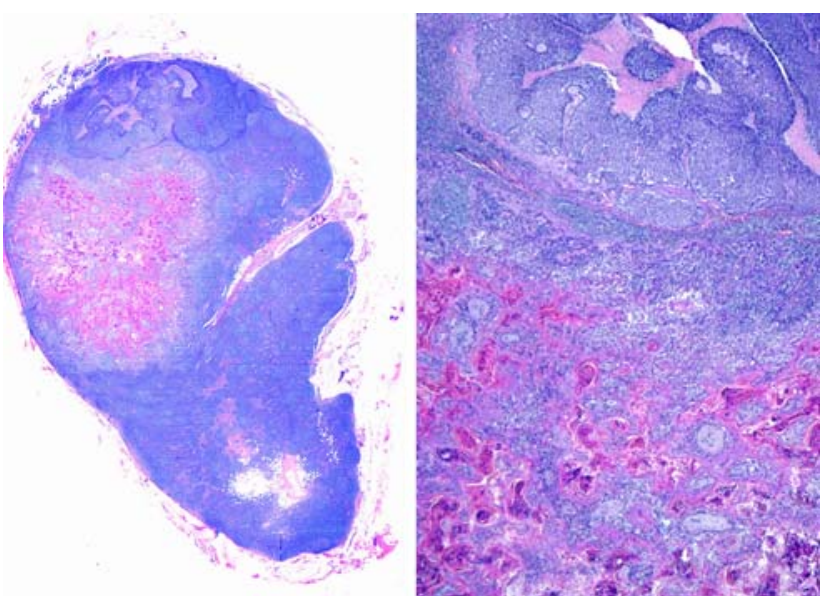

Fig. 8 Lymph node metastasis of a basaloid squamous cell carcinoma of the larynx with the basaloid and squamous components close one to each other

(range, 3-41) for those arising in the oropharynx, and 15.5 months (range, 1-45) for those originating in the oral cavity. Average follow-up for the whole series was 
22.3 months. Overall 3- and 5-year survival was 50\% and $38.5 \%$, respectively. Significant differences in survival were detected between cases with lymph node metastases and cases without $(P<0.05)$.

\section{Discussion}

BSCC has been defined in the 2005 WHO blue book as an aggressive high grade variant of squamous cell carcinoma composed of both basaloid and squamous components [19]. The histogenesis of this neoplasm is controversial. Its first description [1] and the current WHO classification on the Tumours of the Head and Neck [19] suggest the tumour originates from totipotential cells in the basal layer of squamous epithelia.

A review of the literature shows that BSCC appears in both sexes but predominates in males between 60 and 80 years old [19]. Alcohol and tobacco consumption are frequent antecedents. Clinical signs and symptoms are not specific and related to tumour location. The most frequent site is the piriform sinus and supraglottis and our experience agrees with this assertion. The possible relationship of BSCC and viruses is a matter of debate and has been reported in some locations, like nasopharynx [10] and penis [16]. The obtained data are however controversial; while Kleist et al. [20] and El-Mofty et al. [21] have very recently detected a higher frequency of HPV and HSV in basaloid tumours than in conventional squamous cell carcinomas in the head and neck, others [22] have not found any difference.

Grossly, most of the previously reported BSCCs are flat or slightly elevated tumours, often with a central ulceration $[1,4,23]$, and our practice confirms it. Very few cases may show a polypoid pattern. Interestingly, these cases are always associated with a spindle cell component as the third constituent of the tumour [24-26].

It is well known that solid nests with the typical cell population, basaloid at the periphery and squamous at the centre, are the most common growth pattern of BSCCs. This arrangement is distinctive and specific of this tumour and can be recognizable even on fine needle aspiration cytology samples [27]. However, histology relies as the only reliable diagnostic method [1]. A wide range of different additional patterns have been described in BSCC, some of them quite unusual; for example, rosettes [9], cystic spaces, true ductules [1], spherules made of basal membrane material, and PAS+ crystalloids [28]. As previously mentioned, a spindle cell component with epithelial immunophenotype quite infrequently takes part of the tumour [24-26].

By immunohistochemistry, BSCC expresses cytokeratins and EMA. Some authors [19] recommend coktails of keratins composed of Cam 5.2, pankeratin AE/AE3 and CK7, while others $[1,2,29]$ propose the high molecular weight keratin $34 \beta \mathrm{E} 12$ as the most useful marker for this tumour. A "dot-like" pattern with vimentin has been also recorded in these tumours [19]. Most cases are negative with neuroendocrine markers and with S-100 protein [30, 31]. There is no specific immunohistochemical pattern to distinguish this tumour from others and its diagnosis is based on H\&E sections. Quite recently, however, Coletta et al. [32] have demonstrated the importance of cytokeratins 1, 7 and 14 in the diagnosis of BSCC and Emanuel et al. [33] have stressed the value of p63 in making a distinction between BSCC and adenoid cystic carcinoma of the head and neck. These authors [33] show that p63 positivity is diffuse in BSCC and partial in adenoid cystic carcinoma. Immunohistochemistry may be crucial in the recognition and diagnosis of endoscopic biopsies of BSCCs because these biopsies may be superficial or may not sample both basaloid and squamous components of the tumour. In this particular setting, the diagnosis of BSCC is hazardous.

The major histological component of BSCCs is basaloid, so its most important differential diagnosis is the solid variant of adenoid cystic carcinoma [19], another quite infrequent neoplasm. As a matter of fact, adenoid cystic carcinoma does not show any tendency towards squamous differentiation, does contain myoepithelial cells and is essentially devoid of pleomorphic atypical cells, mitosis, and comedonecrosis [23]. Small cell neuroendocrine carcinoma may share some morphological features, mainly in small endoscopic biopsies, but neuroendocrine markers and the "dot-like" immunostaining with keratins identifies it with reliability under the microscope. Some BSCCs contain cysts or pseudoadenoid structures and may mimic adenosquamous carcinoma, another rare entity in the area. The recognition of mucin positivity and true ductulo-acinar differentiation in adenosquamous carcinoma should resolve the dilemma.

The supposed higher clinical aggressiveness of BSCC compared with the conventional squamous cell carcinoma remains a continuous matter of debate. Banks et al. [2], Luna et al. [4], and De Sampaio et al. [34] did not find significant differences in behaviour between these two neoplasms in different anatomical sites, while others [35] did.

Winzenburg et al. [35] were the first authors to correlate some histological variables of BSCC and prognosis. They found that cases with pure basaloid histology and comedonecrosis showed distant metastases in $46 \%$ of the patients and, consequently, fared worse. A predominantly basaloid histology was associated with distant metastases in 52\% of their patients. Something similar happened with cases showing prominent stromal hyalinization, with 53\% 
of patients displaying distant metastases. As many as $76 \%$ of their cases were in Stages III or IV at diagnosis, while only approximately $50 \%$ of our patients did. Surprisingly, their patients with vascular-lymphatic and/or perineural invasion did not present with distant metastases and survival was $100 \%$ [35]. However, we have found vascularlymphatic invasion is an ominous finding, with lymph node metastases and tumour-related death in all of our cases.

Node metastases are a quite common event in laryngeal, hypopharyngeal and tracheal BSCCs since they appear in regional and distant nodes in $75 \%$ and in $35-50 \%$ of the cases, respectively [19]. As reflected since the first series $[1,2,4]$, lymph node status is a key factor in survival. Winzenburg et al. [35] showed significant differences in survival of BSCC with and without lymph node metastases, with survivals of 18.6 and 47.6 months respectively, and our experience confirms it. Distant metastases do also occur in BSCCs with wide numbers ranging from $10 \%$ [4, $36]$ to around $50 \%[1,2,37]$ or even to $75 \%$ [38]. We found them in $15 \%$ of our patients. Lung is the main target for distant metastases in BSCC. Sometimes the clinical status at diagnosis and the evolution of BSCCs seem to be especially aggressive.

Some authors have recently reported the value of p53, Ki-67 and e-cadherin [39], p27 ${ }^{\text {Kip1 }}$ [40], and apoptosis inhibitor protein [41] as independent predictors of prognosis in BSCCs, but these findings need further confirmation in large series and its acceptance and use in daily practice.

Finding a second primary tumour is a common clinical situation in the head and neck and was very soon recognized in BSCC. In fact, McKay and Bilous reported in 1989 [42] a case BSCC in the hypopharynx who showed, in the surgical specimen, a microinvasive squamous cell carcinoma in the left arytenoid region. This possibility was fully recognized by 1991, when Seidman et al. [43] presented a series of 11 BSCCs two of which, with tumours arising in the piriform sinus and vallecula, had synchronic squamous cell carcinomas in the oesophagus and palate, respectively. Associations with tumours outside upper aerodigestive tract have been reported by Banks et al. [2] and Lam et al. [44] in their series of esophageal BSCCs. We have observed it in $17.5 \%$ of our patients and support the Thompson's advice [23] for keeping in mind the possibility of finding a second primary tumour in any site, either synchronic or metachronic, when diagnosing a BSCC in the head and neck.

\section{Conclusions}

In conclusion, BSCC is a distinct clinicopathological entity with aggressive clinical behaviour whose diagnosis still remains on haematoxylin and eosin sections by recognizing the typical histological criteria defined two decades ago. A biphasic pattern of growth, often retained in the lymph node metastases, is the hallmark of the tumour. Immunohistochemistry may be of help in the diagnosis, especially in small endoscopic biopsies in which only a partial view of the tumour is seen. Although supraglottis and piriform sinuses are the most common locations, the entire upper aerodigestive tract is frequently affected. Second primary tumours have been well recognized in these patients.

\section{References}

1. Wain SL, Kier R, Wollmer RT, et al. Basaloid-squamous carcinoma of the tongue, hypopharynx, and larynx: report of 10 cases. Hum Pathol. 1986;17:1158-66.

2. Banks ER, Frierson HF Jr, Mills SE, et al. Basaloid squamous cell carcinoma of the head and neck. A clinicopathologic and immunohistochemical study of 40 cases. Am J Surg Pathol. 1992;16:939-46.

3. Barnes L. Basaliod squamous cell carcinoma. In: Barnes L, editor Surgical pathology of the head and neck, 2nd ed. New York: Marcel Dekker, 2001. p. 184-89.

4. Luna MA, El Naggar A, Parichatikanond P, et al. Basaloid squamous carcinoma of the upper aeorodigestive tract. Clinicopathologic and DNA flow cytometric analysis. Cancer. 1990;66:537-42.

5. Paulino AFG, Singh B, Shah JP, et al. Basaloid squamous cell carcinoma of the head and neck. Laryngoscope. 2000;110:1479-82.

6. Hellquist HB, Dahl F, Karlsson MG, et al. Basaloid squamous cell carcinoma of the palate. Histopathology. 1994;25:178-80.

7. Coppola D, Catalano E, Tang CK, et al. Basaloid squamous cell carcinoma of the floor of the mouth. Cancer. 1993;72:2299-305.

8. Ide F, Shimoyama T, Horie N, et al. Basaloid squamous cell carcinoma of the oral mucosa: a new cases and review of 45 cases in the literature. Oral Oncol. 2002;38:120-4.

9. Wieneke JA, Thompson LD, Wenig BM. Basaloid squamous cell carcinoma of the sinonasal tract. Cancer. 1999;85:841-54.

10. Wan SK, Chan JKC, Lau WH, et al. Basaloid-squamous carcinoma of the nasopharynx. An Epstein-Barr virus-associated neoplasm compared with morphologically identical tumors occurring in other sites. Cancer. 1995;76:1689-93.

11. Saltarelli MG, Fleming MV, Wenig BM, et al. Primary basaloid squamous cell carcinoma of the trachea. Am J Clin Pathol. 1995;104:594-98.

12. Sarbia M, Verreet P, Bittinger F, et al. Basaloid squamous cell carcinoma of the esophagus. Diagnosis and prognosis. Cancer. 1997;79:1871-78.

13. Brambilla E, Moro D, Veale D, et al. Basal cell (basaloid) carcinoma of the lung: A new morphologic and phenotypic entity with a separate prognostic significance. Hum Pathol. 1992;23:993-1003.

14. Chetty R, Serra S, Hsieh E. Basaloid squamous carcinoma of the anal canal with and adenoid cystic pattern. Histologic and immunohistochemical reappraisal of an unusual variant. Am J Surg Pathol. 2005;29:1668-72.

15. Brainard J, Hart W. Adenoid basal epitheliomas of the uterine cervix: a reevaluation of distinctive cervical basaloid lesions currently classified as adenoid basal carcinoma and adenoid basal hyperplasia. Am J Surg Pathol. 1998;22:965-75.

16. Cubilla AL, Reuter VE, Gregoire L, et al. Basaloid squamous cell carcinoma: distinctive human papillomavirus related penile neoplasm. A report of 20 cases. Am J Surg Pathol. 1998;22: 755-61. 
17. Vakar-López F, Abrams J. Basaloid squamous cell carcinoma occurring in the urinary bladder. Arch Pathol Lab Med. 2000;124:455-9.

18. Greene FL, Page DL, Fleming ID, et al., editors. AJCC cancer staging handbook. TNM classification of malignant tumors. New York, 2002.

19. Cardesa A; Zidar N, Ereño C. Basaloid squamous cell carcinoma. In: Barnes L, Eveson JW, Reichart P, Sidrasky D, editors. Pathology and genetics of head and neck tumours. Kleihues P, Sobón LH, series editors. World Health Organization classification of tumours. Lyon, France: IARC Press; 2005. p. 124-5.

20. Kleist B, Bankau A, Lorenz G, et al. Different risk factors in basaloid and common squamous head and neck cancer. Laryngoscope. 2004;114:1063-68.

21. El-Mofty SK, Patil S. Human papillomavirus (HPV)-related oropharyngeal nonkeratinizing squamous cell carcinoma: characterization of a distinct phenotype. Oral Surg Oral Med Oral Pathol Oral Radiol Endod. 2006;101:339-45.

22. Cabanillas R, Rodrigo JP, Ferlito A, et al. Is there an epidemiological link between human papillomavirus DNA and basaloid squamous cell carcinoma of the pharynx? Oral Oncol. 2007;43:327-32.

23. Thompson LDR. Basaloid squamous cell carcinoma (BSCC). In: Thompson LDR, Golblum JR, editors. Head and neck pathology. Philadelphia: Churchill Livingstone; 2006. p. 70-3.

24. Muller S, Barnes L. Basaloid squamous cell carcinoma of the head and neck with a spindle cell component. An unusual histologic variant. Arch Pathol Lab Med. 1995;119:181-2.

25. Kimura T, Mukai M, Shiotani A, et al. Basaloid squamous carcinoma of the hypopharynx with an extensive spindle cell component exhibiting a pedunculated polypoid mass. Arch Pathol Lab Med. 2005;129:94-6.

26. Altrabulsi B, Carrizo F, Luna MA. Spindle basaloid squamous carcinoma of the upper aerodigestive tract: immunohistochemical and clinicopathological study of three cases. Ann Diagn Pathol. 2006;10:149-53.

27. Banks ER, Frierson HF, Covell JL. Fine needle aspiration cytologic findings in metastatic basaloid squamous cell carcinoma of the head and neck. Acta Cytol. 1992; 36:126-31.

28. Zamecnik M, Skalova A, Pelikan K, et al. Basaloid squamous carcinoma with collagenous spherules and crystaloids. Ann Diagn Pathol. 2001;5:233-9.

29. Morice WG, Ferreiro JA. Distinction of basaloid squamous cell carcinoma from adenoid cystic and small cell undifferentiated carcinoma by immunohistochemistry. Hum Pathol. 1998;29:609-12.

30. Hunt JL, Barnes L. Immunohistology of head and neck neoplasms. Basaloid squamous cell carcinoma. In: Dabbs DJ, editor.
Diagnostic immunohistochemistry, 2nd ed. Philadelphia: Churchill Livingstone; 2006. p. 229-30.

31. Klijanienko J, El- Naggar A, Ponzio-Priom A, et al. Basaloid squamous carcinoma of the head and neck. Immunohistochemical comparison with adenoid cystic carcinoma and squamous cell carcinoma. Arch Otolaryngol Head Neck Surg. 1993;119:887-90.

32. Coletta RD, Almeida OP, Vargas PA. Cytokeratins 1, 7 and 14 immunoexpression are helpful in the diagnosis of basaloid squamous cell carcinoma. Histopathology. 2006;48:773-4.

33. Emanuel P, Wang B, Wu M, et al. p63 immunohistochemistry in the distinction of adenoid cystic carcinoma from basaloid squamous cell carcinoma. Mod Pathol. 2005;18:645-50.

34. De Sampaio G, Grizzo FC, Oliviera DT, et al. Prognosis of oral basaloid squamous cell carcinoma and squamous cell carcinoma: a comparison. Arch Otolaryngol Head Neck Surg. 2004;130:83-6.

35. Winzenburg SM, Niehans GA, George E, et al. Basaloid squamous carcinoma: a clinical comparison of two histologic types with poorly differentiated squamous cell carcinoma. Otolaryngol Head Neck Surg. 1998;119:471-5.

36. Erdamar B, Suoglu Y, Sirin M, et al. Basaloid squamous cell carcinoma of the supraglottic larynx. Eur Arch Otolaryngol. 2000;257:154-7.

37. Erisen LM, Coskun H, Ozuysal S, et al. Basaloid squamous cell carcinoma of the larynx: a report of four new cases. Laryngoscope. 2004;114:1179-83.

38. Bahar G, Feinmesser R, Popovtzer A, et al. Basaloid squamous carcinoma of the larynx. Am J Otolaryngol. 2003;24:204-8.

39. Rodriguez Tojo MJ, Garcia Cano FJ, Infante Sanchez JC, et al. Immunoexpression of p53, Ki-67 and E-Cadherin in basaloid squamous cell carcinoma of the larynx. Clin Transl Oncol. 2005;7:100-4.

40. Salerno G, Di Vizio D, Staibano S, et al. Prognostic value of p27Kip1 expression in Basaloid Squamous Cell Carcinoma of the Larynx. BMC Cancer. 2006;6:146.

41. Marioni G, Octaviano G, Marchese-Ragona R, et al. High nuclear expression of the apoptosis inhibitor protein is associated with disease recurrence and poor prognosis in laryngeal basaloid squamous cell carcinoma. Acta Oto-Laryngol. 2006;126:197-203.

42. McKay MJ, Bilous AM. Basaloid squamous carcinoma of the hypopharynx. Cancer. 1989;63:2528-31.

43. Seidman JD, Berman JJ, Yost BA, et al. Basaloid squamous carcinoma of the hypopharynx and larynx associated with second primary tumors. Cancer. 1991;68:1545-49.

44. Lam KY, Law S, Luk JM, et al. Oesophageal basaloid squamous cell carcinoma: a unique clinicopathological entity with telomerase activity as a prognostic indicator. J Pathol. 2001;195:435-42. 